\title{
HELLENISTIC COURT SOCIETY: THE SELEUKID IMPERIAL COURT UNDER ANTIOCHOS \\ THE GREAT, 223-187 BCE
}

\section{Rolf Strootman}

\section{Introduction}

During the Hellenistic Age-roughly the last three centuries BCE-the political history of the eastern half of the Ancient World was dominated by three Macedonian dynasties: the Seleukids, ruling a vast land empire in the Middle East and Central Asia (312-64 BCE); the Antigonid kings of Macedonia, who tried to control Greece and the Balkans until their kingdom was destroyed by the Romans in $168 \mathrm{BCE}$; and the Ptolemies (323-30 BCE), who ruled a maritime empire in the eastern Mediterranean from their capital Alexandria, an empire which comprised Egypt but was not therefore an Egyptian empire. In the second century BCE, the Attalid kingdom, based in Pergamon, emerged as the predominant state in the Aegean region, and around 100 Pontos on the Black Sea and Armenia temporarily became major Hellenistic powers.

Of these states, the empire conquered by Seleukos I Nikator ('The Victorious', ruled 312-281 BCE) was the principal successor state of Alexander the Great (336-323 BCE), who himself had taken over the dominion of the Persian Achaemenids when he defeated the last Persian king, Darius III. In the third century BCE, the Seleukid dynasty laid claim to an empire stretching from the Hindu Kush to the Aegean coast. In 188 the emergent Roman Empire forced Antiochos III to give up Asia Minor. About the same time, Khurāsān was lost to the Parthians. As a result of Parthian expansion the provinces further east became fully independent under Greek rulers. After the death of Antiochos IV in 164 dynastic strife caused a steady decline of the empire until in $64 \mathrm{BCE}$ it disappeared from history almost unnoticed, its former territories being carved up by the Roman, Parthian and Kushan empires. ${ }^{1}$

\footnotetext{
${ }^{1}$ On the empire in general see Elias Joseph Bickerman, Institutions des Séleucides (Paris 1938); Amélie Kuhrt and Susan Sherwin-White, From Samarkhand to Sardis.
} 
In the Seleukid empire new forms of court culture and political ideology developed. A similar evolution took place in the Ptolemaic empire and, through intermarriage and diplomatic exchange, the two dynasties continually influenced each other in this respect. The Seleukid rulers adopted and reshaped the legacy of their Greek, Macedonian and Persian forebears to create a form of monarchy that was neither 'western' nor 'eastern'. Appropriated by the Parthian kings and Roman emperors, the culture and ideology of the Hellenistic courts eventually formed the basis of royal ideology and court culture in both Western Europe and the Islamic East. ${ }^{2}$

Monarchical states, of course, were no new phenomenon in the Ancient world. Until recently, however, the Hellenistic Age has been studied almost exclusively by scholars trained as Greek historians who often tended to consider Hellenistic kingship in contrast with the world of the polis, the autonomous Greek city state. They either disregarded its eastern antecedents or accentuated eastern influences on Hellenistic kingship as perversions of Classical Hellenic culture. Since the 1980's there has been a trend to place Seleukid kingship more thoroughly in an Eastern context, though at times this has led to minimising or ignoring its Greco-Macedonian aspects. ${ }^{3}$

Given the centrality of kingship in Hellenistic studies-traditional historiography sees monarchy as the principal defining element of

\footnotetext{
A New Approach to the Seleucid Empire (London 1993). There are two comprehensive accounts of Seleukid political history, both of them outdated: Edwyn Robert Bevan, The House of Seleucus, 2 vols. (London 1902), and Auguste Bouché-Leclercq, Histoire des Séleucides (232-64 avant J.-C.) 2 vols. (Paris 1913-14). More recent, concise overviews are H. Heinen, 'The Syrian-Egyptian wars and the new kingdoms of Asia Minor', Cambridge Ancient History 7, 1 (1984) pp. 412-45; Christian Habicht, 'The Seleucids and their rivals', in: The Cambridge Ancient History, vol. 8: Rome and the Mediterranean to 133 B.C., A.E. Astin, F.W. Walbank, M.W. Frederiksen and R.M. Ogilvie, eds. (Cambridge 1989) pp. 324-87 and Michel M. Austin, 'The Seleukids and Asia', in: A Companion to the Hellenistic World, Andrew Erskine, ed. (Oxford 2003) pp. 121-133.

${ }^{2}$ For the influence on Roman court culture see Jeremy Paterson, 'Friends in high places: The creation of the court of the Roman emperor', in: The Court and Court Society in Ancient Monarchies, A.J.S. Spawforth, ed. (Cambridge 2007) pp. 121-156.

${ }^{3}$ See e.g. the introduction in Kuhrt and Sherwin-White, From Samarkhand to Sardis, esp. p. 1: "[it is] our firmly held view that the Seleukid kingdom was an eastern empire"; for an example of the completely opposite view, see Burkhard Meißner, 'Hofmann und Herrscher: Was es für Griechen hieß, Freund eines Königs zu sein', Archiv für Kulturgeschichte 82 (2000) pp. 1-36, characterising the Seleukid, Ptolemaic and Antigonid courts as "Höfen im antiken Griechenland" (p. 36).
} 
the age-it is certainly surprising to see that the court has received only very limited attention. Most literature on Hellenistic courts is concerned with institutional or prosopographical aspects of court society. ${ }^{4}$ In addition, the past decades have seen a number of publications on literary patronage at the early Ptolemaic court. ${ }^{5}$ Palace architecture, too, has only recently acquired a place of its own in the bibliography of Hellenistic archaeology. ${ }^{6}$ Attempts at analysis, however, are rare and the advent of modern court studies has not yet made its mark on Hellenistic studies. ${ }^{7}$ Aside from the odd reference

${ }^{4}$ Helmut Berve, Das Alexanderreich auf prosopografischer Grundlage, 2 vols. (Munich 1926); Sylvie le Bohec, 'Les philoi des rois antigonides', Revue des Études Grecque 98 (1985) pp. 93-124; eadem, 'l'Entourage royal a la cour des Antigonides', in: Le système palatial en Orient, en Grèce et à Rome, E. Levy, ed. (Strasbourg 1987) pp. 315-326; Gabriel Herman, "The "friends" of the early hellenistic rulers: servants or officials?', Talanta 12/13 (1980-1981) pp. 103-109; Leon Mooren, The Aulic Titulature in Ptolemaic Egypt. Introduction and Prosopography (Brussels 1975); idem, La hierarchie de cour ptolémaïque. Contribution à l'étude des institutions et des classes dirigeantes à l'époque héllenistique (Louvain 1977); idem, 'The Ptolemaic Court System', Chronique d'Égypte 60 (1985) pp. 214-22; Eckart Olshausen, Prosopographie der hellenistischen Königsgesandten, 2 vols. (Leuven 1974); W. Peremans and E. van 't Dack, Prosopographia Ptolemaica. vi: La cour (Louvain 1968); Chiara Carsana, Le dirigenze cittadine nello stato seleucidico (Como 1996); Ivana Savalli-Lestrade, Les philoi royaux dans l'Asie hellénistique (Geneva 1998).

${ }^{5}$ Alan Cameron, Callimachus and his Critics (Cambridge 1996); Gregor Weber, Dichtung und höfische Gesellschaft. Die Rezeption von Zeitgeschichte am Hof der ersten drei Ptolemäer (Stuttgart 1993); and idem, 'Poesie und Poeten an den Höfen vorhellenistischer Monarchen', Klio 74 (1992) pp. 25-77. On court historians: Burkhard Meißner, Historiker zwischen Polis und Königshof. Studien zur Stellung der Geschichtsschreiber in der griechischen Gesellschaft in spätklassischer und hellenistischer Zeit (Göttingen 1992).

${ }^{6}$ Vera Heermann, Studien zur makedonischen Palastarchitektur (Nürnberg 1986); Inge Nielsen, Hellenistic Palaces. Tradition and Renewal (Aarhus 1994); Gunnar Brands and Wolfram Hoepfner, eds., Basileia. Die Paläste der hellenistischen Könige (Mainz am Rhein 1996); Boney Lea Kutbay, Palaces and Large Residences of the Hellenistic Age (Lewiston; Queenston; Lampeter 1998); Ehud Netzer, Die Paläste der Hasmonäer und Herodes' des Grossen (Mainz am Rhein 1999); Inge Nielsen, ed., The Royal Palace Institution in the First Millennium BC (Athens 2001).

7 Gabriel Herman, 'The court society of the Hellenistic age', in: Hellenistic Constructs. Essays in Culture, History, and Historiography, Paul Cartledge, Peter Garnsey and Erich Gruen, eds. (Berkeley; Los Angeles; London 1997) pp. 199-224, uses Elias but no later literature on courts and court society, and consequently assumes too much freedom on the part of the king in manipulating his courtiers. Meißner, 'Hofmann und Herrscher' ignores even Elias. See further Leon Mooren, 'Kings and courtiers: Political decision-making in the Hellenistic states', in: Politische Theorie und Praxis im Altertum, W. Schuller, ed. (Darmstadt 1998) pp. 122-33; Gregor Weber, 'Interaktion, Repräsentation und Herrschaft. Der Königshof im Hellenismus', in: Zwischen Haus und Staat, Aloys Winterling, ed. (Munich 1997). For a synthesis of older literature see H.H. Schmitt, s.v. 'Hof', in: Kleines Wörterbuch des Hellenismus, H.H. Schmitt 
to Elias' Die höfische Gesellschaft, most Hellenistic historians still study their courts in vacuo. ${ }^{8}$

In my 2007 dissertation about the Hellenistic courts, I tried to reconsider the available sources by making use of insights from the current debate on the early modern European court and state formation. ${ }^{9}$ Thus it was possible, among other things, to re-address the old debate on the significance of Greek culture ('Hellenism') in the east by arguing-against the now prevailing view that Greek influence in the east was negligible - that it was precisely the 'limited' Hellenism of the court which functioned as a means of integrating the various regional elites of the ethnically and culturally heterogeneous empires. Like the Austrian or Ottoman court cultures of later ages, the Hellenism of the Seleukid and Ptolemaic courts was non-national. Court poets and artists consciously created an open, 'universal' Hellenic culture and language in which the regional differences that had been characteristic of Classical Greece were smoothed out. Leading families in the provinces who benefited from the empire, or who aspired to participate in the system of imperial patronage, adopted a double, e.g. HellenisticJewish, Hellenistic-Babylonian, or Hellenistic-Greek, identity as an expression of allegiance and a means of distancing themselves from those excluded from power. ${ }^{10}$ Thus the empire was united at its highest level through a shared elite culture. The royal household served as a point of contact for these otherwise unconnected elites. The upper stratum of the court itself, however, consisted predominantly of ethnic Greeks and Macedonians.

and E. Vogt, eds. (Wiesbaden 1988) pp. 251-57; for a more recent overview Aloys Winterling, s.v. 'Hof', in: Der Neue Pauly (1998) pp. 661-5. For a full bibliography see Rolf Strootman, The Hellenistic Royal Court. Court Culture, Ceremonial and Ideology in Greece, Egypt and the Near East, 336-30 BCE (Utrecht 2007).

8 This may now begin to change: see the excellent introduction by A.J.S. Spawforth in idem, ed., The Court and Court Society in Ancient Monarchies (Cambridge 2007) pp. 1-16.

9 Rolf Strootman, The Hellenistic Royal Court. Court Culture, Ceremonial and Ideology in Greece, Egypt and the Near East, 336-30 BCE (dissertation Utrecht 2007).

${ }_{10}$ Rolf Strootman, 'Van wetsgetrouwen en afvalligen. Religieus geweld en culturele verandering in de tijd der Makkabeeën', in: Religies in interactie. Jodendom en Christendom in de Oudheid, B. Becking and G. Rouwhorst, eds. (Zoetermeer 2006) pp. 79-97; for the multiple identity of ethnic Babylonians see R.J. van der Spek, 'Ethnicity in Hellenistic Babylonia', in: Ethnicity in Ancient Mesopotamia. Proceedings of the 48e Rencontre Assyriologique Internationale, Leiden 2002, W.H. van Soldt, ed. (Leiden 2004). 
In what follows, we will take a closer look at Seleukid court society under one of its most important kings: Antiochos III the Great (ruled 223-187 BCE), whose reign has been documented relatively well in inscriptions and ancient historiography. ${ }^{11}$ Moreover, it was under Antiochos III that the Seleukid Empire reached its greatest territorial extent. ${ }^{12}$ Expansion was accompanied by the establishment of a new imperial order: a system of vassal rulers acknowledging the supremacy of a Great King, which replaced the practice of direct rule through centrally appointed provincial governors, who were often difficult to displace. At the end of Antiochos' reign, however, the empire suffered its first major setback when the king was forced to give up Asia Minor after his defeat in the Roman-Seleukid War of 192-188. ${ }^{13}$

Who were the courtiers surrounding Antiochos III? How were they recruited and how much freedom did the king really have in promoting or demoting the people closest to him? Was there a hereditary aristocracy or was status at court dependent on the favour of the king? ${ }^{14}$ What was the role of regional aristocracies and civic elites, and how were they integrated into the imperial system?

Modern scholarship has created an image of the Hellenistic court in the third century BCE as an 'open' society. The position of courtier was not a hereditary prerogative. The king was able to recruit at will able and loyal men who were given ad hoc responsibilities and could be removed from their positions with relative ease. Thus, the king was in full control of the social composition of his court. This changed only in the second century BCE. Because a system of apparently

${ }^{11}$ For his reign in general see Hermann Bengtson, 'Antiochos III., der Große', in: idem, Herrschergestalten des Hellenismus (Munich 1975) pp. 185-210; D. Bing, 'Antiochus III Megas', Encyclopaedia Iranica 2 (1987) pp. 127-128; Kuhrt and SherwinWhite, From Samarkhand to Sardis. The main historiographical sources are Polybios' Histories, Livy's Ab urbe condita, and Appian's Syrian Wars (Syriaca).

${ }_{12}$ Apart from re-establishing Seleukid suzerainty in Armenia, Iran and Central Asia, Antiochos forced the Indian princes of Gandhara into tributary status, wrested Phoenicia, Palestine and the Anatolian coastline from Ptolemaic control, and added Thrace to his dominions. On the eastern campaigns of Antiochos see Jeffrey D. Lerner, The Impact of Seleucid Decline on the Eastern Iranian Plateau. The Foundations of Arsacid Parthia and Graeco-Bactria, Historia Einzelschriften 123 (Stuttgart 1999) pp. 45-61, and Kuhrt and Sherwin-White, From Samarkhand to Sardis.

${ }_{13}$ For this war and its effects consult R.M. Errington, 'Rome against Philip and Antiochus', in: The Cambridge Ancient History 8 (1989) pp. 244-289; John D. Grainger, The Roman War of Antiochos the Great, Mnemosyne Supplement 239 (Leiden 2002).

${ }^{14}$ Cf. Jeroen Duindam, Vienna and Versailles. The Courts of Europe's Dynastic Rivals (Cambridge 2003) p. 319; Spawforth, Court and Court Society, p. 8. 
hierarchical court titles appears after $200 \mathrm{BCE}$, historians have postulated the development of a 'court bureaucracy', a more 'professional' form of government with specialised office-holders who were consequently no longer under the king's direct control. ${ }^{15}$

It is my contention that as early as the third century the selection of courtiers was much less in the king's hands than official documents suggest. The conflict between Antiochos III and his court at his accession in $223 \mathrm{BCE}$ demonstrates that already by then the free choice of courtiers was no longer de facto a royal prerogative. I will furthermore argue that the evolution of a court hierarchy was a reaction to a changed power balance at the top of the Seleukid Empire rather than its immediate cause.

\section{Empire and City}

Like many large empires, the Seleukid state was basically a tributetaking military organisation, offering protection and benefactions to city states and local princes. To finance its military strength, the empire depended on tribute, paid predominantly by cities. A city represented its hinterlands as well. The city was the place where the agrarian surplus was collected, and part of it turned into cash. Keeping good relations with the many cities in the realm was therefore a principal concern of the Seleukid administration. Seleukid patronage of cities included protection and the granting of various political, economic and religious rights, most notably political autonomy. Cities then repaid their benefactors with tribute or, if the king's grant had been tax-exemption, gifts. In a letter from (presumably) Antiochos II to the city of Erythrai in Asia Minor, perhaps sent shortly after his accession in 261, we read that the king grants the city autonomy and exemption from tribute in return for loyalty and a gift of gold bullion:

King Antiochos to the council and the people of the Erythraeans, greeting. Tharsynon and Pythes and Bottas, your envoys, delivered to us the decree by which you voted the (divine) honours and the crown with which you crowned us, and gave us likewise the gold intended as a gift of

${ }^{15}$ Cf. e.g. F.W. Walbank, 'Monarchies and Monarchic Ideas', in: Cambridge Ancient History 7, 1 (1984) p. 70; Gabriel Herman, Ritualised Friendship and the Greek City (Cambridge 1987) p. 164; Meißner, 'Hofmann und Herrscher', esp. pp. 26-28 and 28-30. 
friendship. Having discoursed on the good-will which you have always held toward our house and on the gratitude which the people entertain toward all their benefactors, and likewise on the esteem in which the city has been held under the former kings, they asked with all earnestness and zeal that we should be friendly to you and should aid in advancing the city's interests in all that pertains to glory and honour. We have then accepted in a friendly spirit the honours and the crown and likewise the gift.... And since Tharsynon and Pythes and Bottas have shown that under Alexander and Antigonos your city was autonomous and free from tribute...we shall help you to maintain your autonomy and we grant you exemption not only from other tribute but even from [the] contributions [to] the Gallic (war) fund. ${ }^{16}$

Because the city is not taxed but presents the king with a 'gift of friendship', it can claim that it is autonomous and deals with the monarchy on the basis of equality; the king receives his tribute nonetheless. Thus, this text, a public inscription reflecting official propaganda, presents the relationship between empire and city as harmonious. ${ }^{17}$ In reality, the simple matrix of tribute and loyalty in exchange for benefactions and protection was open for negotiation and a potential source of conflict.

\section{The Friends of the King}

International networks of aristocratic guest-friendship known in Greek as xenia or philoxenia linked up the royal household with multifarious civic elites. The cement of xenia was philia, a form of ritualised friendship between two persons with traits of fictive kinship. Philia may be defined as a personal, reciprocal bond of loyalty and solidarity between two men (or women) of approximately equal status who share roughly the same interests. They were committed to each other by mutual obligations, and could rely on each other for help. The objective of philia was normally to achieve a common goal, and united action towards that end was a means to strengthen and display the bond. Through the exchange of gifts and favours the friendship was kept alive. The parties

16 OGIS 223 = Michel M. Austin, The Hellenistic World from Alexander to the Roman Conquest. A Selection of Ancient Sources in Translation (Cambridge 1981) no. 183 .

17 See John Ma, Antiochos III and the Cities of Western Asia Minor (Oxford 1999) for an analysis of the rhetoric and ideology of royal and civic letters in the epigraphic record of Seleukid cities in the age of Antiochos III. 
involved in a philia relationship were ideally each other's peers, even when they were not equals in practice. ${ }^{18}$

Xenia and philia were not in themselves typically monarchical. Xenia had been an important aristocratic ideal in Greece since time immemorial, and undoubtedly similar types of bonding existed in various forms in other parts of the Near East as well. ${ }^{19}$ Through participation in a social sphere outside their own city, elite members distanced themselves from their inferiors. Thus xenia relations constituted supranational, 'horizontal' elite networks linking up families of approximately equal social status but of separate social units, particularly cities. ${ }^{20}$ In the Hellenistic Age, these networks became instrumental in the court's policy of influencing the internal politics of cities and supporting oligarchic regimes in order to secure goodwill and loyalty. Conversely, xenia networks offered cities the opportunity to exert influence on political matters at court and to obtain privileges.

It was through the instrumentality of philia that men attached themselves to the royal household (oikos), and thus became 'courtiers', serving the king as court officials, ambassadors or military commanders. ${ }^{21}$ Hence Hellenistic courtiers were commonly known as philoi tou basileoss, 'Friends of the King', although the title of royal philos did not in itself presuppose actual presence at court. ${ }^{22}$ As we have seen in the letter of Antiochos to Erythrai, the interdependence of city and monarchy, too, was explained in terms of philia, with its ideology of mutual aid and benefit, and equality. The relationship between city and king was therefore embedded in the moral complex of gift exchange, as we saw in the inscription from Erythrai.

${ }^{18}$ Herman, Ritualised Friendship; cf. David Konstan, Friendship in the Classical World (Cambridge 1997). For the function of gift-exchange at the Hellenistic courts see Strootman, Hellenistic Royal Court, pp. 143-148.

19 For philia as an Archaic Greek aristocratic ideal see Mary Scott, 'Philos, philotes and xenia', Acta Classica 25 (1982) pp. 1-19, and Hans van Wees, Status Warriors. War, Violence and Society in Homer and History (Amsterdam 1992) pp. 44-48.

${ }^{20}$ Herman, Ritualised Friendship, p. 200.

21 Herman, Ritualised Friendship, p. 208.

22 The word aule (literally 'court') is most often used in Greek historiography to denote a royal household. To distinguish between courtiers and philoi who were not actually at court, ancient historians sometimes speak of peri tēn aulèn, 'people of the court', or aulikoi; however, despite Bickerman 1938's assertion that these were technical terms, unlike philoi they do not figure in official contemporary documents. The word therapeia, 'retinue', sometimes is used to describe the philoi surrounding the king. For the terminology in the sources see further Strootman, Hellenistic Royal Court, pp. 13-4, and 119 n. 67. 
The royal friends played a crucial role in the negotiations between city and king both directly and indirectly. Directly, they could act as negotiators on behalf of their own cities of origin. They represented the interests of the cities at court and the interests of the court in the cities, deriving benefits from their membership of both systems. ${ }^{23}$ Indirectly, philoi could act as intermediaries between the royal power and embassies seeking audience at court. For such arbitration cities could reward philoi with public honours, citizen rights and gifts. At court, they could obtain military commands, landed estates, privileges and favours for themselves, their families, their cities and their own clients, and status.

Being continually on campaign, the courts of the Seleukid kings were peripatetic. There was no fixed capital. The Seleukids maintained palaces in cities all along the Royal Road, the main artery connecting the eastern and western edges of the empire. In the third century these included Sardis in Lydia, Antioch and Apameia in Syria, Seleukeia in Babylonia, Susa in Elam, Ekbatana in Media, Balkh in Baktria, and probably Merv in Margiana. Also the great palace excavated at Aï Khanoum in north-east Afghanistan was in all likelihood originally a Seleukid palace, perhaps built by Antiochos I. When the king was absent, these palaces served as governors' residences. Wherever they came, the Seleukids made ceremonial entries into cities and participated in local religious festivals. ${ }^{24}$ They were always accompanied by their court and the main army.

${ }^{23}$ Gabriel Herman, 'Friendship', in: Oxford Classical Dictionary, Simon Hornblower and Antony Spawforth ed. (Oxford 1996) pp. 611-3, at p. 613. On philoi as mediators between king and cities see Klaus Bringmann, 'The king as benefactor: Some remarks on ideal kingship in the age of Hellenism', in: Images and Ideologies. Self Definition in the Hellenistic World, A.W. Bulloch et al. ed. (Berkeley; Los Angeles; London 1993) 7-24. Herman, 'The "friends" of the early Hellenistic rulers' has listed civic decrees honouring philoi, mainly from third century Athens, Samos, Ephesos and Delos. Cf. Herman, 'The court society of the Hellenistic age'; Ivana Savalli-Lestrade, 'Courtisans et citoyens: le cas des philoi attalides', Chiron 26 (1996) pp. 149-81; F. Muccioli, 'La scelta delle titolature dei Seleucidi. Il ruolo dei philoi e delle classi dirigenti cittadine,' Simbolos 3 (2001) pp. 295-318. The pivotal significance of philia for Seleukid imperialism is captured by a letter to the city of Miletos in which Seleukos II assures the citizens that he is well-disposed to the city because the friends of his deceased predecessor have informed him about the loyal attitude of Miletos towards his family: I.Didyma 493; OGIS I 227; Welles, RC 22 lines 7-9. For Milesian philoi at the Seleukid court see P. Hermann, 'Milesier am Seleukidenhof. Prosopographische Beiträge zur Geschichte Milets im 2. Jhdt. v. Chr.', Chiron 17 (1987) pp. 171-92.

${ }^{24}$ Strootman, Hellenistic Royal Court, pp. 289-298, 308-314. 


\section{Antiochos' Accession}

Antiochos III succeeded to the throne unexpectedly in 223/2 BCE when his brother, Seleukos III, was assassinated by some of his courtiers while on campaign in Asia Minor. ${ }^{25}$ Antiochos, then about twenty years old, was absent from the court when the king was murdered. As in the Classical Ottoman Empire, or Qing China, it was customary that the brothers of the reigning Seleukid king be kept away from the centre of power. Antiochos' accession immediately caused a vicious power struggle in which two rival factions at court vied for the favour, or rather, the control of the young king. The conflict is described in detail by the historian Polybios, who wrote only several decades after the events had taken place. ${ }^{26}$ At the same time, the satraps of Media and Persis, the brothers Molon and Alexandros, who had been appointed by the former king, rebelled against his successor. Such conflicts were normal. Virtually every new reign sooner or later saw attempts of the new king to replace the men who had risen to positions of power under his predecessor by his own philoi, and hence also attempts by the predecessor's philoi to retain their positions. ${ }^{27}$ Molon and Alexandros, too, may have rebelled partly from fear of, or in reaction to, attempts at their being replaced. Although Antiochos, as we shall see, was ultimately successful in these enterprises, it was no matter-ofcourse that a Hellenistic king was able to manipulate the composition of his sunedrion, the royal (war) council. ${ }^{28}$

According to Polybios, power at first came into the hands of a certain Hermeias the Karian, a trusted philos of the former king who had been left as viceroy at Seleukeia on the Tigris when Seleukos III moved into Asia Minor. Although he was not at court at that time, he probably owed his initial supremacy to the fact that the successor, Antiochos, was with him at Seleukeia, the most important of the Seleukid

${ }_{25}$ Appian, Syriaca 66; cf. Polybios 4.48.7-10.

${ }^{26}$ Polybios 5.40.-56; Polybios' informants were insiders at the Seleukid court, including a grandson of Antiochos III, Demetrios, to whose philia network Polybios belonged when they both lived as exiles in Rome.

${ }_{27}$ Note that in the inscription from Erythrai, cited above, the king at the beginning of his reign speaks explicitly of the advice given by his father's friends, patrikoi philoi, whom apparently he regarded as his own.

${ }^{28}$ Polybios is aware that decisions at court are not always made by the king, but the historian, he says, 'is obliged to ascribe to the ruler the opinion which prevailed at his councils' (4.24.2); cf. Mooren, 'Kings and courtiers', esp. p. 131. 
capitals, and was inaugurated there. His superior position was soon contested when the philoi who had accompanied Seleukos on his campaign returned from Anatolia with the main army. Their leader was a general called Epigenes, who was popular with the troops. A third prominent philos of Seleukos III, Achaios, remained in Asia Minor to continue the war. Like Molon and Alexandros, he too refused to accept Antiochos as king. Because Hermeias was so powerful and was taking all the decisions and preventing Antiochos from appointing his own associates to key positions, the king allied himself with Epigenes' faction. Or so it seems: perhaps Antiochos, who later proved to be one of the most competent monarchs ever to rule the Seleukid empire was in reality playing off Hermeias against the other courtiers of his brother. ${ }^{29}$

Epigenes fell when the army mutinied over arrears of pay. Hermeias offered to pay the troops from his own funds, but demanded in return that Epigenes and his followers be banished from the court:

The king was much displeased with this proposal... but troubled as he was by Hermeias' machinations and enthralled by the obligations of the court, and permanently surrounded by a host of guards and courtiers, he was not even master of himself, so that he gave way and acceded to the request. ${ }^{30}$

As soon as Epigenes was driven from court, Hermeias produced a letter evidencing his having sided with the rebels, and had him summarily executed: 'The king was forced to admit that Epigenes had merited

${ }^{29}$ Polybios' impression of things, however, is problematic. By supporting the established philoi who had been favoured by his brother, the king weakened his own position. If we pursue this point somewhat further, it becomes even doubtful whether the king in reality supported Epigenes' faction at all. Hermeias is described by Polybios as a typical 'wicked advisor' in constant conflict with the court in such a way that we may reasonably ask whether he was not in reality the king's favourite. Cf. e.g. Polybios 5.41.3: Hermeias 'was jealous of all the holders of prominent court offices, and as he was naturally of a savage disposition, he inflicted punishment on some for errors which he magnified into crimes, and trumping up false charges against others, showed himself a cruel and relentless judge.' Also the haste with which Antiochos rid himself of Hermeias after the latter had succeeded in destroying Epigenes points in that direction.

${ }^{30}$ Polybios 5.50.4-5. Hellenistic kings often relied for funds on wealthy philoi, cf. Strootman, Hellenistic Royal Court, p. 147. An anecdote about Ptolemaios V (Diodoros 29.29) suggests that it was not unusual for the Ptolemaic king to borrow money from his courtiers to finance campaigns, later to pay them back with interest from the war booty; thus we hear that Apollonios, the wealthy Ptolemaic courtier and land-owner known from the Zenon Papyri, had become rich from trading slaves from Syria. 
his own fate,' Polybios writes, 'and the courtiers, though they had their suspicions, were afraid to utter them'. ${ }^{31}$ Only after Antiochos had achieved two resounding military victories-against the rebel satraps in Babylonia and against the Armenian king Artabazanes-were his prestige and wealth sufficient to stand up against Hermeias and his entourage. He was then able to remove them from court as well ${ }^{12}$ and replace them with his own intimates. Below, we will see who these new courtiers were and how they were recruited.

\section{The Courtiers of Antiochos III}

As we saw above, the accession of Antiochos III was accompanied by violent struggles among the philoi of his predecessor, Seleukos III, who were afraid they would lose their status and offices under the new king. ${ }^{33}$ Simultaneously, a number of Seleukos' philoi who were not at court rebelled under the leadership of Molon, the satrap of Media. In the end, this rebellion was put down with surprising ease: although the satraps' forces had already destroyed two royal armies that had been sent against them, the troops refused to fight when confronted with the legitimate king in person and surrendered; the rebel satraps committed suicide and were replaced by lesser governors who had remained loyal. ${ }^{34}$

Of the three most influential philoi in the reign of Seleukos III two were dead by the winter of 222/221 BCE. The third, Achaios, the viceroy of Asia Minor, had allied himself with Molon upon Antiochos'

31 Polybios 5.50.14.

32 Hermeias could not be disposed of easily. See details in Polybios 5.56.7, Polybios 5.56.12, and the posthumous accusation against Hermeias in Polybios 5.55.5.

${ }^{33}$ We are informed that also Attalos III of Pergamon and the Seleukid king Alexandros I Balas eliminated the philoi of their predecessors upon their accession (Diodoros 34-34.3; Livy, Periochae 50). The court of Alexander the Great, too, was troubled by the king's constant and increasingly violent attempts to rid himself of the established court grandees who dominated his council, and to replace them with his own confidants, cf. Strootman, Hellenistic Royal Court, pp. 96-101; Sabine Müller, Maßnahmen der Herrschaftssicherung gegenüber der makedonischen Opposition bei Alexander dem Grossen (Frankfurt am Main 2003). The difficulties encountered by both Alexander and Antiochos, two of the strongest kings in Hellenistic history, and the devious and violent methods they resorted to, suggest that their ultimate success in manipulating the personal composition of their courts was exceptional.

${ }^{34}$ Polybios 5.54.4. Achaios body, like Molon's, was mutilated and crucified, the common punishment for 'betrayal'. 
accession and openly rebelled in 220. His planned invasion of Syria and Babylonia was hampered by the fact that his troops, too, refused to fight the king directly. ${ }^{35}$

With the most powerful philoi of his predecessor and their followers out the of way, Antiochos proceeded to make new appointments in the army and provincial government-together with membership of the sunedrion the main indicators of rank at court. We are relatively wellinformed about the composition of Antiochos' court in various phases of his reign, the principal sources being Livy, Appian and, again, Polybios. In addition, there is epigraphic evidence, mainly from western Asia Minor ${ }^{36}$ Who were these men? How were they recruited and how was their loyalty secured?

The inner circle of the king at first consisted of young men of his own age class. The Seleukid court had a system of royal pages, basilikoi paides, sons of the king and of important, particularly Macedonian philoi as well as, presumably, non-Greek aristocrats, who were brought up at court. Under the guidance of a regent known as a tropheus, one of the most important court offices in the Hellenistic world, they were educated and trained as military commanders. They guarded and waited in attendance on the king. The system had been institutionalised at the Macedonian court of Philip and Alexander. ${ }^{37}$ Men who had in their youth been pages together with the reigning king, could later be awarded the honorific title of suntrophos, 'foster-brother' of the king, and were addressed by him as 'brother'. Such philoi were really friends of the king. Notably Alexander the Great had used his circle of suntrophoi as the main source for recruiting favourites. Antiochos III initially promoted his former fellow-pages to important positions, too, but royal suntrophoi did not dominate his court as they had dominated Alexander's. One powerful suntrophos at his court was a certain Philippos, who held the prestigious post of elephantarchos, commander of the war elephants, throughout Antiochos' reign. ${ }^{38}$ Another

${ }_{35}$ Allying himself with a number of Anatolian peoples, and supported by Ptolemy IV, Achaios held out until 216 until Antiochos arrived personally in Asia Minor, and Achaios lost most of his support. He finally fell into Antiochos' hands through treason and was executed for disloyalty (Polybios 4.48; 5.41, 57, 66; 8.19-21).

${ }^{36}$ The epigraphical evidence has been collected by Savalli-Lestrade 1998.

${ }^{37}$ N.G.L. Hammond, 'Royal Pages, personal pages, and boys trained in the Macedonian manner during the period of the Temenid monarchy', Historia 39, 3 (1990) pp. 261-290; Strootman, Hellenistic Royal Court, pp. 181-188.

${ }_{38}$ Polybios 5.82.8; Livy 37.41.1; Appian, Syriaca 33. 
was Antipatros, whom Polybios calls a 'brother of the king. ${ }^{39}$ Like Philippos, Antipatros in all likelihood was an (ethnic) Macedonian. Together with Zeuxis (about whom more shortly) Antipatros was the most trusted of Antiochos' courtiers. He commanded the cavalry on the left flank in the battles of Raphia (217 BCE) and Magnesia (190), and was Antiochos' principal ambassador during the peace negotiations following these battles with a mandate to accept terms in the name of the king. ${ }^{40}$ Command of the left flank in battle was a position of honour indicative of very high status. It was reserved for the crown prince or the most important philos, the right flank being commanded by the king himself. ${ }^{41}$ In the battle against Molon in 221 it had been Hermeias who commanded the left flank, together with Zeuxis.

With Zeuxis we have arrived at a second category of courtiers who rose to prominence early in Antiochos' reign. These were the philoi who had been office-holders of secondary rank when Antiochos succeeded to the throne, and had proven their loyalty during the war with Molon. After the defeat of Molon, and the deaths of Epigenes, Hermeias and Achaios, they took over their positions. Thus, Diogenes the military governor (stratēgos) of Susiana (Elam), who had defended the citadel of Susa against the rebels, was given Molon's satrapy of Media. ${ }^{42}$ The first prize went to Zeuxis, who possibly was satrap of Babylonia under Seleukos III and thus perhaps an older and more experienced man than Antiochos. ${ }^{43} \mathrm{He}$, too, had remained loyal to the king during the revolt, resisting Molon's offensive in Babylonia with only a small

${ }^{39}$ Polybios 5.79.12 and 87.1; cf. Livy 37.41.1 and 55.3; Philippos' title of adelphos was honorific.

${ }^{40}$ Polybios 21.7.9. Antipatros as commander: Polybios 5.79.12, cf. 16.18.7; Livy 37.41.1. As ambassador: Polybios 5.87.1; 21.16.4; Livy 37.45.5-6; 37.55.3, and 56.8.

${ }^{41}$ Thus, in the great battles of Alexander the Great, this position was reserved for Parmenion, whether Alexander liked that or not. Crown princes commanding the left flank include: Alexander at the Battle of Chaironeia; Antiochos (I), the son of Seleukos Nikator, at Ipsos (Plutarch, Demetrios 29.3); Antiochos, the son of Antiochos III at Panion; and Seleukos (IV) son of Antiochos III together with Antipatros at Magnesia (Livy 37.41.1).

${ }_{42}$ Polybios 5.46.7, 48.14; 5.54.12. Diogenes later accompanied Antiochos on his eastern campaign, fighting the Parthian king in Hyrkania in 209 BCE (Polybios 10.29.5, 30.6-9), but thereafter disappears from the sources. Diogenes' place as stratēgos of Susiana was taken by a certain Apollodoros, while Tychon, the chief secretary (archigrammateus) of the army, was given the Persian Gulf region as province (Polybios 5.54.12). The lesser commanders in Molon's satrapy were pardoned and maintained their positions (5.54.8).

${ }^{43}$ According to Josephus, Jewish Antiquities 12.148, Antiochos honoured Zeuxis with the title of 'father', which may imply that he had been the tropheus of Antiochos 
army.$^{44}$ After Antiochos had arrived on the scene with the main army, Zeuxis began to take part in the meetings of the sunedrion. ${ }^{45}$ Together with Hermeias he commanded the left flank of the royal army in the final battle against Molon. ${ }^{46}$ After having distinguished himself as a general in the Fourth Syrian War against the Ptolemies (219-217), Zeuxis was installed as satrap of Lydia and viceroy of Asia Minor, a function he held at least from the beginning of Antiochos' campaigns in Iran and Central Asia in 211 until the king's return to Asia Minor in 199. His service as viceroy is well-attested in the epigraphical record. In the historiographical sources he turns up again during Antiochos' wars in Asia Minor and Greece (199-190) as a military commander and ambassador. ${ }^{47}$ At the end of his reign, Antiochos promoted his by then adult sons to high offices in the army and the administration: first the crown prince Antiochos, who died in c. 193, and subsequently Seleukos, the later king Seleukos IV Philopator (ruled 187-175). It is relevant to note here that Seleukid heirs were not really 'crown princes', for no such thing existed in Macedonian tradition; to forestall succession strife, the king's chosen heir was raised to the status of basileus, 'king', during the father's lifetime. ${ }^{48}$

and his suntrophoi Antipatros and Philippos, and explain his exceptional loyalty and commitment to Antiochos' cause.

${ }^{44}$ Polybios 5.45.4, 46.11, 48.12.

${ }^{45}$ Polybios 5.51.5. Interestingly, also Apollophanes of Seleukeia, the physician who had played a key role in the elimination of Hermeias, became a member of the royal council (Polybios 5.58.3).

${ }_{46}$ Polybios 5.53.6-7.

${ }^{47}$ Zeuxis commanded part of the infantry in the Battle of Magnesia (Livy 37.41.1, cf. Appian, Syriaca 33). In 190, Zeuxis and Antipatros were commissioned to negotiate a peace with the Roman consul Scipio and Eumenes of Pergamon (Polybios 21.16.5; Livy 37.45.5); the two men later travelled to Rome to ratify the peace (Polybios 21.24.1). This treaty entailed first of all the loss of Zeuxis' own province of Asia Minor. For philoi serving their king as ambassadors see Leon Mooren, 'Die diplomatische Funktion der hellenistischen Königsfreunde', in: Antike Diplomatie, Eckart Olshausen and Hildegard Biller, eds., Wege der Forschung 162 (Darmstadt 1979) pp. 256-290.

${ }^{48}$ See Strootman, Hellenistic Royal Court, pp. 111-14. The moral superiority of the father over the son hierarchised this system of dual kingship, while the presence of other sons secured the junior king's loyalty. Similarly, one of the king's wives could be raised to the status of basilissa, meaning 'queen' in her own right (or: 'female king'), not 'wife of the king', which was called basilinna in Greek, cf. Grace Harriet Macurdy, Hellenistic Queens. A Study of Woman-Power in Macedonia, Seleucid Syria, and Ptolemaic Egypt (Baltimore 1932) p. 8; Elizabeth D. Carney, "What's in a Name?" The Emergence of a Title for Royal Women in the Hellenistic Period', in: Women's History and Ancient History, Sarah B. Pomeroy, ed. (Chapel Hill; London 1991) pp. 154-172. Antiochos the son as commander in the Fifth Syrian War: Polybios 16.18.5-8. As viceroy of the Middle East during the Seleukid-Roman War: 35.13.4-5. Seleukos installed 
Still it seems that Antiochos had to reckon with opposition from his courtiers, as the men most favoured, apart from those mentioned above, were in some way or other outsiders among the philoi. We see a distinct preference on the part of the king for patronising defectors from rival courts, and exiles-men who had, forcibly or voluntarily, abandoned their earlier social milieu and had become dependent on the favour of a new patron. ${ }^{49}$ When an influential philos changed sides, members of his own personal network of friends followed him. ${ }^{50}$

Theodotos the Aitolian was governor of southern Syria and Palestine for Ptolemy IV, and in that capacity had successfully defended his province against the advance of Antiochos' army in $221-220 .{ }^{51}$ As he did not receive a proper reward during his next visit to Alexandria, 'holding the king in contempt... and mistrusting the court circles', Theodotos felt so insulted that he decided to offer his services to Antiochos; ordering his generals to occupy strategic positions, he offered Antiochos the cities that were under his control and urged him to enter his province with his army. ${ }^{52}$ In the ensuing Fourth Syrian War, Antiochos confirmed Theodotos as governor of his province (which he lost again after the Seleukid defeat in the Battle of Raphia in 217). ${ }^{53}$ Theodotos was given prestigious positions in the Seleukid army, including command of the Silver Shields, the royal infantry guard. ${ }^{54}$

as viceroy in Thrace: Polybios 18.50.8; Livy 35.15.4-5, cf. 36.7.15. As general in Asia Minor: Livy 37.11.15, 18.1-5, 21.6; Appian, Syriaca 26. As co-ruler of the empire: Livy 35.13.4-5; V. Messina, "Presto sarò re": Seleuco IV come Helios sulle cretule da Seleucia al Tigri', Parthica 3 (2001) pp. 9-23.

${ }^{49}$ The prominence of exiles at court is also emphasised by James L. O'Neil, 'The Ethnic Origins of the Friends of the Antigonid Kings of Macedon', Classical Quarterly 53 (2003) pp. 510-522, esp. 516: "Such men did not have an independent power base and were reliant on royal favour for their influence".

${ }^{50}$ Polybios 5.70.10.

${ }^{51}$ Polybios 5.61.3.

${ }^{52}$ Polybios 5.40.1-3, 61.4-9.

${ }^{53}$ Polybios 5.66.5. Theodotos made himself a name for daring when on the eve of the battle he sneaked into the Ptolemaic camp with two companions in an (abortive) attempt to kill king Ptolemy, and thus take his revenge (Polybios 5.81.1-7). The history of Antiochos III shows that it was not unusual for philoi to change their allegiance and associate themselves with rival courts (pace Meißner, 'Hofmann und Herrscher', pp. 15-16), the main reason for their 'treason' being the impugnation of their honour when their patron did not live up to the obligations of philia.

${ }^{54}$ Polybios 5.79.3; 7.16.1-18.10. 
Alexandros the Akarnanian had been a key office-holder at the court of the Antigonid king Philip V. ${ }^{55}$ When Philip became an ally of Rome, Alexandros attached himself to the Seleukid court and immediately made an exceptional career. As a member of Antiochos' sunedrion he advised the king concerning the conquest of mainland Greece, and served him as a general until he was mortally wounded in the Battle of Thermopylai (191). ${ }^{56}$

The admiral Polyxenidas was exiled from his native town of Rhodes. He held several commands during Antiochos' eastern campaigns, was a member of the sunedrion, and during the war against Rome and her allies (including Rhodes) commanded Antiochos' Aegean fleet. After suffering two major defeats, Polyxenidas of Rhodes eventually succeeded in destroying a large part of the Rhodian fleet in the combined land and naval battle at Panormos, taking his revenge on the Rhodian admiral Pausistratos, a personal enemy who had offended him, and who was killed in the battle. ${ }^{57}$

Our last example is the best known philos of Antiochos the Great, and his principal favourite in the final part of his reign: Hannibal of Carthage. Hannibal sought refuge at the Seleukid court in 196 after his defeat by Scipio in the Second Punic War. He became a senior advisor of Antiochos during the Seleukid-Roman War. ${ }^{58}$ Although the Carthaginian commander was obviously an anomaly in the Seleukid sunedrion, distrusted and hated by the other philoi, Hannibal nevertheless enjoyed the full confidence of the king, who sought and followed his advice in personal interviews and gave him important commands. ${ }^{59}$ Hannibal appears in the sources as a typical favourite, an outsider who stands up against the other courtiers and supposedly brings the king under his influence.

Antiochos' most trusted favourite, however, was neither a defector nor an exile but his principal wife, Laodike, the daughter of his vassal Mithradates II of Pontos. For various reasons, queens were considered

\footnotetext{
${ }^{55}$ His title epi tēs therapeias (Polybios 4.87.5 and 8) means either 'captain of the bodyguard' or 'major-domo'.

${ }^{56}$ Livy 35.18.1-8; 36.11.6, 20.5-6.

${ }^{57}$ Polybios 10.29.6; Livy 36.41.7, 43.4-7; 37.8.1-4, 10.3-5, 11.7-14, 23.7, 24.5-11, 26.5-8, 28.4, 30.1-10, 45.2; Appian, Syriaca 14; 17; 21; 22; 24; 27.

${ }^{58}$ Livy 34.42.6-14, cf. 37.45.16; Polybios 21.17.

${ }_{59}$ Distrusted by the philoi: Livy 34.14.4-5, 19.1; 41.2-3, 42.5-14; cf. Appian, Syriaca 10. Trusted by the king: Diodoros 29.3; Livy 34.19.7, 42.6-14; 36.6.7, 15.2, 41.2, cf. 34.7.1-21; 37.8.3, 24.4.
} 
trustworthy persons to whom power could be delegated, especially when a king was on campaign far from the geographical core of his empire. Thus, when Antiochos III was campaigning in the Aegean, Laodike represented him as monarch, having authority over the royal treasury, as is apparent from a letter to the city of Iasos, which had suffered from an unspecified natural disaster:

Queen Laodike to the council and people of Iasos, greetings. Having often heard my brother recall the help he constantly provides to his friends and allies,... and since it is my policy to act in accordance with his zeal and eagerness, (I will) confer a benefaction on those citizens who are destitute, which would be of general advantage to the entire people, I have written to Strouthion, the financial official (dioikètess), to have brought to the city every year for ten years 1,000 Attic medimnoi of corn to be delivered to the people's representatives.... If you continue to be (well) disposed towards my brother and in general towards our house as is fitting, (and) gratefully remember all our benefactions, I will try to help in securing in every way the other benefits I intend to confer, acting in accordance with the wishes of my brother. For I know that (he) is very eager to bring about the restoration (of the) city. Farewell. ${ }^{60}$

Because of the Macedonian practice of polygamous marriage and the absence of primogeniture, the Seleukid dynasty did not in principle have an official crown prince. There were, however, means by which a king could favour one of his sons ${ }^{61}{ }^{1}$ The mother of the king's favourite son could be expected to be a most loyal ally and to regard the interests of her husband's family as her own, lest her son be removed from the centre of power and replaced by the son of another wife as the designated successor. ${ }^{62}$

Above we have seen three categories of people who rose to positions of power in the early reign of Antiochos: first, members of the young king's own age class, former royal pages who had grown up

${ }^{60}$ Austin, Hellenistic World from Alexander to the Roman Conquest, no. 156; SEG 26, 1226 (c. 195).

${ }^{61}$ Cf. n. 48 , above.

${ }^{62}$ In Laodike's letter to Iasos, the dyad of king and queen is emphasised by the queen's designation of her husband as 'brother', and her dominant position among the king's wives by her use of the title of 'queen' (basilissa); in his correspondence from the field, Antiochos III likewise emphasised that Laodike was his other self by calling her 'our sister and basilissa', cf. Austin, Hellenistic World from Alexander to the Roman Conquest, nos. 151 and 158. Often competition among court factions organised around the respective queens and their sons, destabilised the Seleukid court or even led to succession war; for a comprehensive overview of all occasions see Daniel Ogden, Polygamy, Prostitutes and Death. The Hellenistic Dynasties (London 1999). 
together with him; second, magistrates and officers who had held positions of secondary rank in the preceding reign and were rewarded for their loyalty to the new king by promotion to the upper stratum of the court, taking over the positions of the powerful figures whose downfall they had helped to accomplish; and third, defectors, exiles and other outsiders who served as favourites. The promotion of favourites later in Antiochos' reign as a counterweight to balance the power of the philoi, suggests that the latter had become an established group with relatively secure positions at court and in the government. What we have also seen is how in the Seleukid Empire positions at court were linked directly with positions in the government and the army.

\section{The Ethnicity of the Seleukid Ruling Class}

In an influential article, Christian Habicht calculated that in the third century a mere $2.5 \%$ of the Seleukid imperial elite consisted of nonGreeks. He based his conclusion on a sample of about 250 leading men in the empire, using their personal names as indication of their ethnicity. ${ }^{63}$ Frank Walbank commented that 'The exclusion of nonGreeks from this circle probably reflected the prejudices of the Greeks and Macedonians rather than any incapacity or reluctance to serve on the part of the indigenous population. ${ }^{64}$

In the past decades, Habicht's view of the Seleukid court as an ethnically homogeneous group has become an object of controversy. The supposed ethnocentrism of the court seemed difficult to reconcile with the Seleukid Empire's nature as a Vielvölkerstaat and the existence of powerful autochthonous elites in rural areas and non-Greek cities. The principal arguments against Habicht's calculation have been collected by Kuhrt and Sherwin-White; apart from several methodological objections, they argued that Greek personal names do not necessarily indicate Greek ethnicity since non-Greeks in high positions would probably assume Greek names. ${ }^{65}$

${ }^{63}$ C. Habicht, 'Die herrschende Gesellschaft in den hellenistischen Monarchien', Vierteljahrschrift für Sozial- und Wirtschaftsgeschichte 45 (1958) pp. 1-16. Cf. Herman, 'Court Society of the Hellenistic Age', p. 201.

${ }^{64}$ F.W. Walbank, 'Monarchies and Monarchic Ideas', p. 68.

${ }^{65}$ Kuhrt and Sherwin-White, From Samarkhand to Sardis, pp. 124-5, cf. pp. 150-1. Leah McKenzie, 'Patterns in Seleucid Administration: Macedonian or Near Eastern?', Mediterranean Archaeology 7 (1994) pp. 61-68, goes even further by arguing that 
Although it is certainly true that personal names are flimsy indicators of ethnicity, the philoi at Seleukid court often figure in the sources with an ethnikon attached to their name, and from this evidence it seems that Habicht may have been right after all. ${ }^{66}$ Furthermore, ethnicity is not a matter of genealogy alone; it is also to some degree a cultural construct. ${ }^{67}$ If non-Greeks indeed gained access to court, yet assumed a dual identity, this did not make them ethnic 'Greeks', but it does testify to the dominance of Greeks and Macedonians at court. Finally, the rare non-Greek courtiers who do turn up in the sources unconcealed were favourites who had risen to prominence precisely because they were outsiders.

Under Alexander the Great, members of the Persian ruling class had initially retained their positions. As Macedonian hegemony was not yet firmly established, Alexander and his immediate successors, including Seleukos I, had to come to terms with the settled elites of the former Achaemenid Empire in order to pacify and govern the conquered territories. Some were allowed a place of honour at the Macedonian court, but most were merely confirmed in positions in the provincial administration. ${ }^{68}$

Already at the end of Alexander's reign efforts had been made to replace Iranian satraps with Macedonians, a policy which was continued by his successors. The Achaemenid aristocrats reacted to their exclusion from the empire's upper level by retreating to their rural power bases in relatively peripheral and little urbanised regions like northern Anatolia, Armenia and southern Iran. While French aristocrats in the seventeenth and eighteenth centuries would compensate for their loss of power in the provinces by attaching themselves to the royal court, ${ }^{69}$ the former Achaemenid elites drew away from the Seleukid court because they could gain in the periphery what they had lost in the centre. During the third century the Seleukids maintained

since the Seleukid administration combined Persian and Macedonian elements, an infrastructure was created that welcomed non-Macedonians, which in turn encouraged the creation of a shared culture.

66 Strootman, Hellenistic Royal Court, pp. 124-9. Cf. Weber, 'Interaktion, Repräsentation und Herrschaft', pp. 40-1; Herman, 'The Court Society of the Hellenistic Age', p. 208.

${ }^{67}$ Greek identity as a cultural construct: Jonathan Hall, Ethnic Identity in Greek Antiquity (Cambridge 1997); Irad Malkin, ed., Ancient Perceptions of Greek Ethnicity (Cambridge, Mass.; London 2001).

${ }^{68}$ Strootman, Hellenistic Royal Court, pp. 131-132.

${ }^{69}$ Duindam, Vienna and Versailles, p. 10. 
bonds of friendship and alliance with these local dynasts. Seleukos I was married to an Iranian noblewoman from Sogdia, the mother of his successor Antiochos.

\section{Governors into Kings}

In the reign of Antiochos III, indigenous, non-Greek aristocrats re-emerged as independent regional rulers. In his Armenian campaign of 212 and the so-called anabasis, Antiochos' great eastern campaign between 211 and 205, the king violently forced independent dynasts and unruly satraps into submission, then made them kings by his own grace. In return for their acceptance of his suzerainty, the Seleukid king offered his vassals protection. Thus, the 'governor' Zariadris became ruler of western Armenia, Xerxes of Armenia proper, Arsakes of Parthia, Demetrios of Baktria and Sogdia, and Sophagasenos of Gandhara. In Persis (Fars), the Persian heartland, a dynasty was founded by a local priest-king known as frataraka. Antiochos also accepted the existence of autonomous dynasties in Pontos, Kappadokia and Kommagene. The alliances between Antiochos and his vassals were cemented by dynastic marriages. With the exception of the Macedonian Demetrios, these dynasts were all non-Greeks. Regional rulers struck their own coins. Some of them, in particular the Parthian king and the frataraka of Persis, were depicted on coins wearing a kyrbasia, the satrapal cap, over the royal diadem. Apparently, these regional kings were still fitted into a court-based system of rank.

Although the new arrangement of the empire may have been a reaction to growing regional independence, that did not necessarily mean that the empire was weakened. The revolts of Molon and Achaios had demonstrated how difficult it could be to replace governors once appointed and in control of a provinces' resources and armed forces. To put it simply, the Seleukid court developed from an institution where high military offices were distributed into one where the title of king could be obtained. ${ }^{70}$ This process had in fact started before

${ }^{70}$ The Roman and Parthian Empires continued in the Middle East the Seleukid system of imperial rule through dependent autonomous kingdoms, cf. RolfStrootman, 'Queen of Kings: Kleopatra vii and the "Donations of Alexandria"', in: Kingdoms and Principalities in the Roman Near East, Margerita Facella and Ted Kaizer eds. (Stuttgart 2010) pp. 139158; a similar claim has recently been made by Maria Brosius, The Persians (London; New York 2006) pp. 114-116. After the disappearance of the Seleukid dynasty, the 
Antiochos' reign, when Seleukos III (246-225) formally accepted the autonomy of the Parthians, and was not able to suppress the growing independence of his Baktrian satrap, Diodotos. However, it seems that the change from a system of more or less direct rule by appointed provincial governors to a system of indirect rule through vassal dynasties was institutionalised under Antiochos, who assumed the title of Great King on his return from the east. ${ }^{11}$

Notwithstanding the rise of non-Greek, particularly Iranian elites, Antiochos' court continued to be dominated by ethnic Greeks tied to Greek poleis, with a small upper stratum of ethnic Macedonians. ${ }^{72}$ Iranians and others probably were increasingly present at court but they were not among the circle of persons closest to the king. From the available sources it is impossible to determine the exact status of 'Orientals' at court; perhaps their informal influence was greater than the 'western' historians Polybios and Livy suggest. Also the non-Greek troops that formed the majority of Antiochos' army in the great battles were almost without exception commanded by Greek and Macedonian senior officers. This dominance was not necessarily the consequence of an active policy on the part of the king; it may as well have been the result of the existence of an established, hereditary court aristocracy of Greek land-owners whose families had served the Seleukids for generations and who were not willing to give up their positions to newcomers. $^{73}$ This question, however, must at present remain inconclusive.

What we do see at this time, is the beginning of the development of a more refined system of aulic hierarchy and titulature, and this may

imperial court in Rome became the place where the princes of the Middle East turned to for confirmation of their royal status.

${ }^{71}$ So also Brosius, The Persians, p. 115.

72 Strootman, Hellenistic Royal Court, p. 126. Of the 41 office-holders and commanders who are known by name and ethnic, only three were non-Greeks. Apart from Hannibal, these were Aspasanias 'the Mede', commander of 5,000 Iranian light infantry in the Battle of Raphia, and Zabdibelas, an Arabian ally or vassal who commanded 10,000 'Arabs and neighbouring tribes' in the same battle (Polybios 5.79.7 and 8); nine of them, counting the king's sons Antiochos and Seleukos, were Macedonians.

${ }^{73}$ It is only in the course of the second century BCE that we hear more often of Iranian favourites being promoted to positions of power at the Seleukid court; at the same time, Egyptian favourites became a common presence at the Ptolemaic court. In both cases, they are described as eunuchs. See Strootman, Hellenistic Royal Court, pp. 177-178, for references; cf. R. Strootman, 'Eunuchs, concubines and renegades: The "paradox of power" and the promotion of favorites in the Hellenistic Empires', in: A. Erskine and L. Llewellyn-Jones eds., The Hellenistic Royal Court (forthcoming). 
well have been related to the rise of new elites in the course of the third century.

\section{Court Titulature: Offices and Honorific Titles}

Hellenistic court titulature grew from the basal system of titles of the fourth century Macedonian court, and developed through the adoption of Achaemenid practices into a more complex and refined system in the third century. Distribution of titles was part of the complex of gift exchange at court. Titles were presented by the king as rewards, comparable to, and presumably coming together with, material gifts of honour. In the third century, philoi mainly carried the type of titles that Léon Mooren in the context of Ptolemaic titulature has classified as 'real aulic titulature'-titles indicating concrete court functions, to be distinguished from 'honorific titulature', titles awarded honoris causa-and military offices. ${ }^{74}$ The latter category, omitted by Mooren, includes the generic titles of stratēgos, archistratēgos and satrap, as well as specific ones like elephantarchos. ${ }^{75}$ To the former category belong such offices as major-domo, Master of the Pages (tropheus), Chief Physician (archiatros), Chief Secretary (archigrammateus), Captain of the Bodyguard, Master of the Hounds, and Queen's Chamberlain. More honorific titles were Kinsman of the King (sungenès tou basileōs, perhaps an originally Achaemenid title) and Foster-Brother of the King (suntrophos tou basileoss). Similar or comparable titles existed at the Ptolemaic court and it is clear that the two dynasties influenced each other. ${ }^{76}$ The evidence however is unclear, as we rarely are informed what these functions implied in actual practice.

${ }^{74}$ Mooren, Aulic Titulature, p. 2.

${ }^{75}$ Military titles were indicative of status at court, court and army being interwoven; high officers in the army were always at the same time philoi, and the philoi mentioned by Polybios as members of Antiochos' royal council were also his supreme military commanders in the field. For a different view see however Herman, 'Court Society of the Hellenistic Age', p. 214 and K. Ehling, 'Der "Reichskanzler" im Seleukidenreich', Epigraphica Anatolica 30 (1998) pp. 97-106, assuming a formal distinction between 'civil' and 'military' office-holders at the court of Antiochos III.

${ }^{76}$ Bickerman, Institutions des Séleucides, p. 31; Mooren, Aulic Titulature, pp. 2 and 5. In the third century, the Antigonids stuck to the old Macedonian titles predating Alexander, retaining for instance the honorific office of somatophulax 'royal bodyguard' at the heart of the court hierarchy (cf. e.g. Diodoros 30.10.2, 30.11.1; on this title in Alexander's reign: Strootman, Hellenistic Royal Court, pp. 97-98. 
From c. 200 BCE onwards, purely honorific titles appear that suggest a hierarchisation of the philoi. Thus we hear of such titles as First Friends (prōtoi philoi), Honoured Friends (timōmenoi philoi), and First and Highly Honoured Friends (prōtoi kai prōtimōmenoi philoi) at both the Seleukid and Ptolemaic courts. ${ }^{77}$ What exactly these designations implied is impossible to reconstruct but it is safe to assume that they indicated status differences. A hierarchisation of court titulature may have been advantageous for the king. ${ }^{78}$ However, it could as well have functioned as an instrument for the established Greek philoi at the top of court society to close their ranks and to secure positions and privileges, both vis-à-vis outsiders and courtiers of lesser rank as well as vis-à-vis the king.

It is likely, but difficult to prove, that the later Seleukid kings had to reckon with an established social group of Greek court aristocrats who had become a landowning class due to the land distributions with which the monarchy in the past had rewarded their ancestors for their services. The existence of an established aulic aristocracy with fixed privileges and prerogatives at court may be confirmed by my earlier point that Antiochos III favoured Iranian and other indigenous dynasties-landed aristocracy without prerogatives at court-as provincial and municipal rulers, replacing temporary governors recruited among (Greek) philoi. Whether the king did so voluntarily or simply accepted new power relations that were ultimately beyond his control, is irrelevant for the present argument. What counts, is the result. Cemented by dynastic marriages, the principal bond between the king and his

${ }^{77}$ Kay Ehling, 'Gelehrte Freunde der Seleukidenkönige', in: Gelehrte in der Antike. Alexander Demandt zum 65. Geburtstag, A. Goltz, A. Luther and H. SchlangeSchöningen, eds. (Cologne; Weimar; Vienna 2002) pp. 41-58, esp. p. 45, and F. Muccioli, 'Crisi e trasformazione del Regno Seleucide tra il II e il I Secolo A.C.: titolatura, ruolo e competenze dei suggeneis', in: Politics, Administration and Society in the Hellenistic and Roman World, Leon Mooren ed. (Louvain 2000) pp. 251-274, esp. p. 260, perhaps assume too much 'frozen formalism' (Herman, 'Court Society of the Hellenistic Age', p. 223) for the title system. Although this honorific titulature is best attested for the Ptolemaic empire (see e.g. Mooren, Aulic Titulature, and idem, La hierarchie de cour ptolémaïque; Herman, 'The "friends" of the early Hellenistic rulers') it is impossible to determine where the system originated; Bickerman, Institutions des Séleucides, p. 31 suggested that it was imported into the Ptolemaic court when Antiochos III's daughter Kleopatra married Ptolemy V in 194/3.

${ }^{78}$ Weber, 'Interaktion, Repräsentation und Herrschaft', explained it as a mechanism by which the king could retain the loyalty of his philoi, since he was unable to recruit new friends among the Aegean Greeks, who were no longer willing to attach themselves to a declining empire. 
non-Greek allies was kinship. Through kinship ties, non-Greek elites must have gained access to the royal household, perhaps even to the inner court directly surrounding the king. Moreover, local aristocrats visited the court for great occasions such as inaugurations and weddings, as well as for major religious festivals. ${ }^{79}$ The historian Diodoros says that Antiochos IV in organising a festival of Apollo and Artemis at Daphne in 166/5 BCE 'brought together the most distinguished men from virtually the whole inhabited world... and, as it were, put upon a stage his entire empire (basileia)'. ${ }^{80}$

Since, however, in the second and first centuries non-Greeks still do not appear in the sources as among the persons closest to the king in any substantial numbers, we may assume that they were consciously excluded. The evolution of a more or less hierarchical and formalised complex of aulic titulature cannot but have served as a means to regulate proximity to the throne. Those non-Greeks who did participate in the distribution of offices and titles, had to adopt the forms and values of court culture, becoming 'Greeks' in more or less the same way that Turks, Arabs or Serbs became Ottomans when serving the padishah in Constantinople. A case in point is the Judean aristocrat Yannai, who had forcibly captured the high-priesthood of Jerusalem around 150 BCE. The Seleukid king, Alexandros I Balas, confirmed him in this office, giving him the titles of philos and adelphos of the king along with a purple court dress and a golden wreath. ${ }^{81}$ Yannai, who adopted the Greek name Jonathan, was able to accumulate massive power as a Seleukid ally, taking advantage of the dynastic wars that weakened the central power. His brother Simeon, who succeeded him in 142, founded the Hasmonean dynasty, a Seleukid vassal state renowned for the Hellenism of its court.

\section{Conclusion}

In the recent past, scholars studying the Ancien Régime have 'attacked the notion of "absolutism", stressing the financial limits of monarchical

\footnotetext{
${ }^{79}$ See e.g. 1 Maccabees 10.51-66.

${ }^{80}$ Diodoros 31.16.1; cf. 2 Maccabees 18-20, where Jewish delegates from Jerusalem travel to Tyros where the king celebrates the annual festival of Melkart-Herakles.

${ }^{81} 1$ Maccabees 10.20; cf. 10.62. The wreath was a gift of honour, often given as a reward for valour in battle.
} 
rule and the resilience of regional powers. ${ }^{82}$ As far as the Hellenistic kingdoms are concerned, however, the myth of absolutism is still alive. As Spawforth wrote: 'In the nineteenth and twentieth centuries the students of monarchical institutions in the ancient world have often been preoccupied with modernist attempts to define their legal basis. ${ }^{83}$ As a result, historians often fail to distinguish between the official rhetoric of imperialism and the more complicated reality of power relations, postulating a real and virulent absolutism for Alexander and his successors, who ruled their empires and courts unhindered by any constitutional regulations. This is true first of all for the relationship between kings and cities. Although the old notion that the Greek city state declined 'after Chaironeia' is now challenged more often, the opinion that Hellenistic cities lacked political freedom and had no voice in the affairs of the monarchies of which they formed part, still prevails. But the declaration of the autonomy and freedom of the cities, the most popular slogan in Hellenistic royal propaganda, was not a hollow phrase. ${ }^{84}$ Through the agency of the philoi, cities were able to negotiate with the empire, often to their own great advantage. The philoi not only acted on behalf of the king vis-à-vis the cities, but also promoted the interests of the cities at court.

As the problems accompanying the accession of Antiochos III have shown, Hellenistic kings were also not the absolute masters of their own courts. Even though Antiochos initially succeeded in rearranging the social composition of his court, he later ruled primarily through favourites who were relative outsiders within the society of philoi: Macedonians, defectors from rival courts, refugees from the Greek mainland, a Carthaginian outlaw, and a queen. We also saw how the king was forced to acknowledge the rising power of autochthonous aristocracies. Antiochos reacted by expanding an already ongoing process of indirect rule through local dynasts. The new vassals were fitted into the imperial superstructure through dynastic marriages and the facilities of the court, which they or their ambassadors visited on specific festive and ceremonial occasions. Adopting the Hellenism of the court, local rulers and civic elites became in part Hellenised as an

\footnotetext{
${ }^{82}$ Duindam, Vienna and Versailles, p. 10.

${ }^{83}$ Spawforth, Court and Court Society in Ancient Monarchies, pp. 1-16.

${ }^{84}$ Rolf Strootman, 'Kings and cities in the Hellenistic Age', in: The Postclassical Greek City. Volume II: Political Culture. Richard Alston, Onno van Nijf, and Christina Williamson eds. (in press).
} 
expression of their allegiance to the imperial court. Conversely, the Seleukid kings themselves shaped their monarchical representation to match the expectations of their heterogeneous subject peoples, particularly in religious contexts. They always took care, however, to fit these respective cultural 'faces' into an umbrella culture and ideology of empire which in essence remained Hellenic. 